\title{
E-læring - overvejelser om kursusplanlægning og kursusudvikling
}

\author{
Pia Larsen \\ Lektor, Ph.D. \\ Forskningsenheden for Statistik \\ Syddansk Universitet \\ p.v.larsen@stat.sdu.dk
}

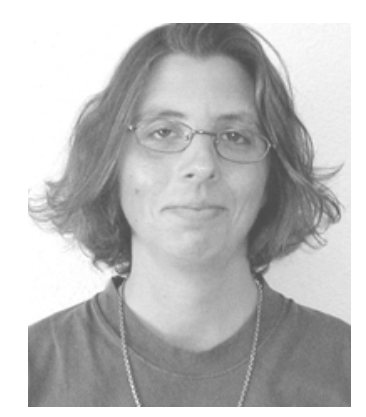

Pia Larsen er lektor i statistik ved Syddansk Universitet i Odense, hvor hun bl.a. har varet med til at udvikle en netbaseret mastergrad i anvendt statistik. Udover undervisning og fremstilling af undervisningsmateriale har hun medvirket til udviklingen af en kursusskabelon til prcesentation af undervisningsmateriale på Internettet. Hun har tidligere vcret ansat ved The Open University i England, hvor hun bl.a. har arbejdet med fjernundervisning i statistik.

\section{Indledning}

Denne artikel er et forsøg på at konkretisere nogle af de mange overvejelser omkring kursusplanlægning og kursusudvikling, der er forbundet med at tilrettelægge et kursus til fjernstuderende. Artiklen koncentrerer sig om det arbejde, der ligger forud for undervisningen, mens de praktiske og pædagogiske udfordringer, der knytter sig til den faktiske undervisning, ikke betragtes her. Disse problematikker behandles f.eks. i Georgsen (2003), der beskriver og diskuterer forskellige lærings- og kommunikationsformer i det virtuelle rum, Ponti \& Ryberg (2004), der slår til lyd for det virtuelle rum som et socialt knudepunkt i læringsmiljøet, mens Duus \& Ehlers (2004) opstiller en række kompetencekrav til den virtuelle underviser (coach).

Indeværende artikel er primært baseret på forfatterens betragtninger og refleksioner i forbindelse med planlægningen og udviklingen af kurset ST111: Regression and Analysis of Variance, som er en del af den netbaserede masteruddannelse Master of Applied Statistics (MAS). Der gives først en kort introduktion til MAS-uddannelsen, hvorefter der fokuseres på overvejelser vedrørende udvikling af undervisningsmateriale henholdsvis kursuspræsentation. Afslutningsvis kommenteres erfaringerne fra to forløb af kurset ST111.

\section{Baggrund om MAS}

De stadig større krav, der stilles til dataindsamling og databehandling i det private erhvervsliv og i den offentlige forvaltning, har medført en stigende efterspørgsel på medarbejdere, der er i stand til at til at udføre og fortolke statistiske analyser korrekt. For at imødekomme efterspørgslen udbyder fire danske forsknings- og undervisningsinstitutioner (Syddansk Universitet, Danmarks Tekniske Universitet, Den Kongelige Veterinær- og Landbohøjskole, og Danmarks Jordbrugsforskning) i fællesskab en 2 1/2-årig deltidsuddannelse i anvendt statistik: Master of Applied Statistics.

Formålet med MAS er at give overblik over moderne anvendte statistiske metoder, samt indføring i praktisk databehandling ved brug af tidssvarende statistisk software. Derudover lægges vægt på skriftlig formidling af statistiske analyser. Der kræves for at deltage i uddannelsen en relevant bacheloruddannelse eller tilsvarende med kurser i både matematik og 
statistik, samt mindst to års relevant erhvervserfaring, hvor statistik indgår som et væsentligt element.

MAS er netbaseret, og kurserne undervises via e-læringsplatformen Blackboard. Endvidere præsenteres undervisningsmaterialet til de fleste af kurserne i MASkel, en netbaseret kursusskabelon udviklet af SDU. MAS-uddannelsen udbydes hvert andet år og består af 8 kvarterskurser á 6 ECTS, hvoraf flere er valgfrie, samt et masterprojekt (12 ECTS).

Første gennemløb af MAS startede i efteråret 2003 med omkring 12 studerende (antallet varierer lidt mellem kurserne, da de også kan tages som enkeltfag). Det første hold studerende afsluttede uddannelsen med et masterprojekt i januar 2006. Andet forløb startede i september 2005 med cirka 20 studerende. Kurset ST111: Regression and Analysis of Variance er det andet obligatoriske kursus i uddannelsesforløbet og har i skrivende stund haft to gennemløb, senest i efteråret 2005.

\section{Udvikling af undervisningsmateriale}

Mange af mine overvejelser omkring udvikling af materiale til fjernundervisning har hentet inspiration fra The Open University i England, som i mange år har udbudt fjernundervisning i stort omfang og med stor succes.

En af deres grundsætninger er at "en god lærebog er ikke nødvendigvis det samme som godt fjernundervisningsmateriale”. En lærebog skal fungere i samspil med forelæsninger, hvor den skal supplere og underbygge forelæserens fortolkninger og diskussionsoplæg. I fjernundervisning er de studerende i første omgang alene med undervisningsmaterialet - først når materialet er gennemgået på egen hånd, deltager de i diskussioner, gruppearbejde, projektarbejde, osv.

\section{Overblik og struktur}

Nogle af de typiske bidrag fra forelæsningerne i tilstedeværelsesundervisning er overblik over emnet, vægtning af forskellige aspekter indenfor emnet, sammenhæng med tidligere moduler, osv. Endvidere sikrer de, at der kan blive samlet op på eventuelle misforståelser med det samme. Tiltag, der kan nedtone behovet for disse bidrag i fjernundervisning, er at have klare og entydige formuleringer i kursusmaterialet, at fremhæve og gentage hovedtræk, at diskutere og eksemplificere sammenhænge og forskelle mellem alternative metoder, og at tydeliggøre den røde tråd i kurset. Ydermere kan hvert modul med fordel udstyres med et summary, en liste med keywords, case studies, og/eller en repetitionstest f.eks. en elektronisk multiple choice test.

I det aktuelle kursus skal de studerende bruge den statistiske programpakke SAS. Der er altid en fare for, at "teknikken" ender med at blive fokuspunktet for de studerende frem for det fagrelevante stof, når software er en del af et kursus. En udførlig vejledning i den nødvendige programmering, samt eksempler, opgaver og afleveringsopgaver med vægt på faglige fortolkninger kan hjælpe til med at flytte fokus væk fra teknikken.

Endelig virker et kursus mere indbydende og inspirerende, hvis undervisningsmaterialet er praktisk organiseret og pænt præsenteret. Desuden kan dette medvirke til at forebygge forvirring og usikkerhed. Et eksempel på en måde at præsentere netbaseret undervisningsmateriale på, er den skabelon, MASkel, SDU har udviklet i forbindelse med MAS-uddannelsen. Hensigten var at skabe en skabelon, der på den ene side var nem og praktisk for brugeren, og på den anden side fleksibel nok til at understøtte forskellige kurser med forskellige behov. (Skabelonen henvender sig primært til tekniske fag, da den er LaTeXbaseret.) Figur 1 viser en side fra ST111, hvor hvert modul er opdelt i 
- Modultekst (hovedtekst)

- Eksempler (case studies)

- Opgaver (praktiske opgaver i dataanalyse)

- Computernoter (vejledning i programmering i SAS)

Det er muligt at klikke sig frem og tilbage mellem dokumenterne indenfor hvert modul og modulerne imellem. Der er også en søgefunktion, der kan finde stikord i hele kurset.

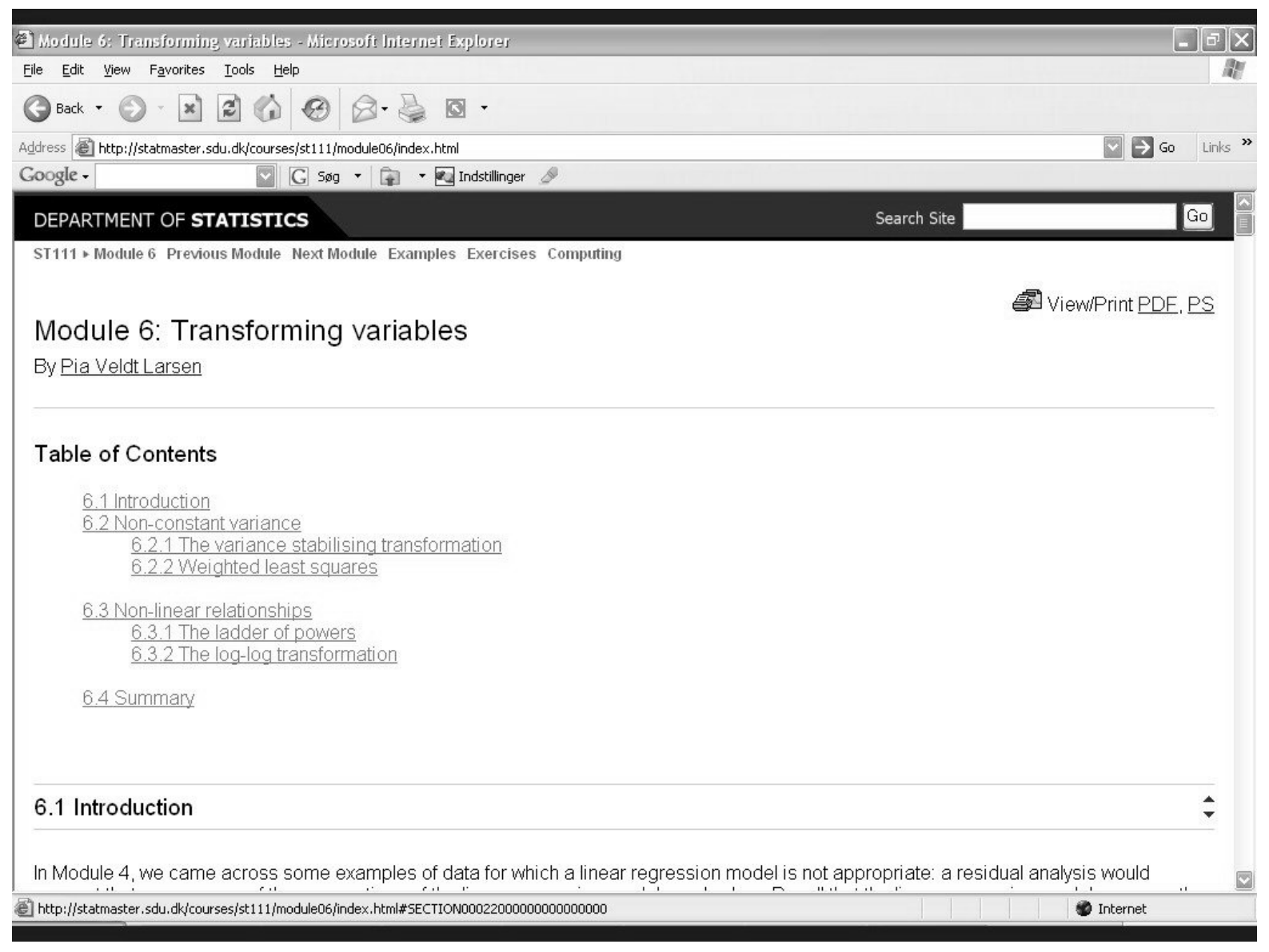

\section{Figur 1. Kursusskabelonen MASkel}

\section{Motivation og intuition}

En simpel skitse på tavlen, et lille eksempel fra dagligdagen, argumentation ud fra figurer og eksempler, er nogle af de intuitive midler, man i forelæsninger impulsivt bruger til at motivere udledningen af (statistiske) metoder og formler. For en fjernstuderende, kan det være en god hjælp, at disse intuitive argumenter er skrevet eksplicit ned i teksten - selvom de måske virker "oplagte" eller "trivielle".

For masterstuderende med fuldtidsjob ved siden af, kniber det til tider med at afsætte den nødvendige tid og energi til studiet. En motivationskilde, der kan hjælpe med at holde de studerende engagerede, er brugen af virkelige (ægte) data/problemstillinger i eksempler og opgaver. Foruden at tydeliggøre relevansen af det aktuelle emne bliver det lettere for de studerende at koble formler, resultater og fortolkninger direkte til anvendelser indenfor deres eget fagområde eller i deres arbejde. En yderligere motivationskilde er at tillade brugen af egne data og problemstillinger i opgaver og projekter. 


\section{Aktivering}

En måde at aktivere de studerende på, mens de gennemgår undervisningsmaterialet, er ved at indsætte små aktiviteter i teksten. For eksempel små opgaver eller spørgsmål, der tilskynder dem til selv at overveje næste trin, inden de læser videre. Større praktiske opgaver i anvendelse af de gennemgåede metoder giver tekniske færdigheder og ofte anledning til debat i diskussionsforummet.

Jævnlige obligatoriske opgaver eller fremlæggelser sikrer, at alle følger (nogenlunde) med i kurset og øger ofte aktiviteten i diskussionsforummet - både før og efter afleveringsfristen. Gruppeopgaver stimulerer samarbejde mellem de studerende, mens individuelle opgaver giver den enkelte studerende mulighed for få individuelle kommentarer fra underviseren.

\section{Præsentation af kursus}

Når studerende for første gang deltager i et e-læringskursus, opstår der nemt usikkkerhed om, hvordan de skal gebærde sig i det virtuelle rum, og hvilke forventninger der stilles til dem. Denne tvivl kan hurtigt lede til frustrationer, som medfører en dårlig stemning i kurset (og ekstra arbejde til underviseren, når trådene skal redes ud).

\section{Overskuelighed og klare linier}

Jo nemmere de studerende har ved at finde rundt i kurset, jo flere kræfter kan de bruge på faglige frem for praktiske og tekniske spørgsmål. Mange problemer og utilfredshed kan undgås ved at lægge klare linier fra starten (hvad forventes der af de studerende, og hvad kan de forvente - og ikke forvente! - af underviseren), og ved at holde overskuelighed på undervisningsplatformen, så det er let at finde frem til alle praktiske oplysninger, henvisninger til FAQ-/hjælpesider, vejledninger i installation af software osv.

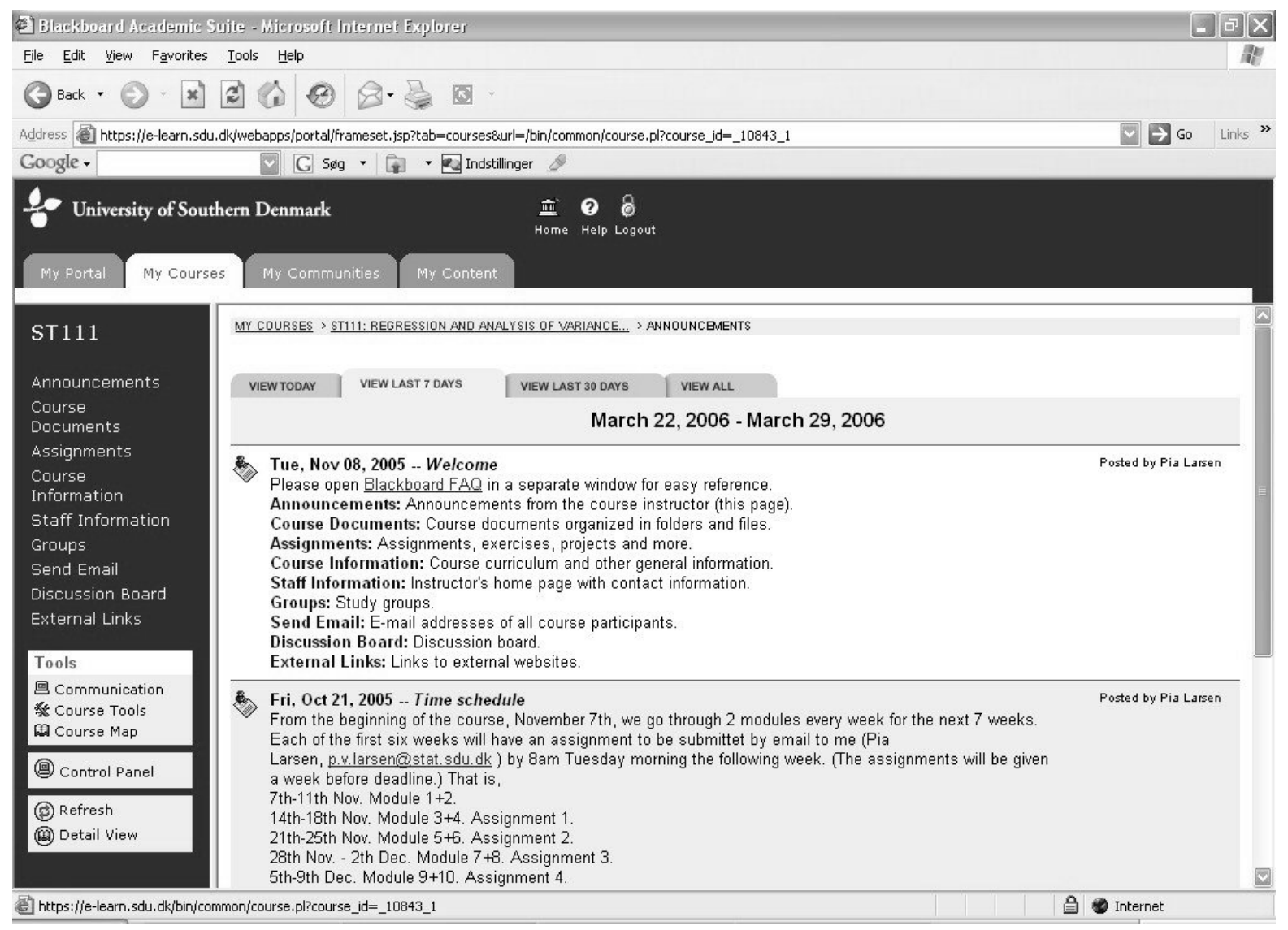

Figur 2. Hvad, hvor og hvornår i Blackboard 


\section{Elektroniske muligheder}

Det virtuelle diskussionsforum, chat funktioner, fælles elektronisk tavle, video, ... er blot nogle af de mange muligheder, man kan udnytte i e-læring. Dertil kommer fildeling, elektroniske evalueringer og repetitionstest (med øjeblikkelig respons), muligheden for prompte opdateringer af links og undervisningsmateriale, o.m.a.

En blid måde at introducere de studerende til diskussionsforummet på, er at bede dem om at præsentere sig selv i et indlæg. Præsentationerne kan eventuelt herefter danne basis for gruppeopdeling. E-tivities og et særskilt ikke-fagligt forum styrker det sociale miljø og kan sætte liv i aktiviteten, hvis diskussionen er ved at gå i stå.

\section{Tekniske vanskeligheder}

Et forhold, der om noget kan føre til frustrationer i e-læring, er hvis (når) der opstår computerproblemer. Det er svært at koncentrere sig om faglige spørgsmål, hvis man samtidig skal bakse med computertekniske vanskeligheder. Selv med grundig forhåndstestning af al software til kurset, og udførlige vejledninger i installation og anvendelse, kan der opstå uforudsete problemer. En back-up plan og/eller en tilknyttet computertekniker, som kan løse eventuelle problemer med det samme, kan hjælpe med at sikre at fokus forbliver på det faglige.

For tekniske og matematiske fag som statistik kompliceres den skriftlige kommunikation af klodsede og meget tidskrævende formeleditorer og mangel på de nødvendige symboler. Indtil disse forhold forbedres i standard e-læringsplatforme, må man nøjes med at benytte en tillempet tekstbaseret notation, som måske nok fungerer, men er langtfra optimal.

\section{Erfaringer fra to kursusforløb}

Som nævnt har kurset ST111 i skrivende stund haft to forløb. I forbindelse med udviklingen af kurset til første forløb i 2003 forsøgte jeg at indarbejde de omtalte overvejelser, bl.a. ved at bygge undervisningsmaterialet op over intuitiv argumentation og eksempler med virkelige data såvel i grundteksten, som i case studies og opgaverne til hvert modul. For at sikre aktiv deltagelse i kurset blev der stillet obligatoriske ugentlige individuelle afleveringsopgaver, som blev rettet og kommenteret af underviserne. Endvidere blev stillet en række frivillige opgaver, som de studerende blev opfordret til at gennemgå gruppevis. Som afsluttende eksamensprojekt kunne de vælge enten at lave en rapport over en analyse af egne data, eller en rapport over et projektoplæg stillet af underviserne.

Kurset blev særdeles positivt modtaget af de studerende (Tabel 1). Især blev kursusmaterialet og tilbagemeldingen på de individuelle afleveringsopgaver fremhævet. Der var også stor tilfredshed med muligheden for at benytte egne data i eksamensprojektet, hvilket blev udnyttet af ca. halvdelen af kursisterne. Gennemsnitstiden brugt på kurset var lidt lavere end de forventede 15 ugentlige timer på grund af et vist overlap med det foregående kursus.

\begin{tabular}{|l|c|c|}
\hline Spørgsmål: & Gennemsnit (2003) & Gennemsnit (2005) \\
\hline Did the course meet your expectations? & 5.13 & 5.05 \\
\hline $\begin{array}{l}\text { Did the teaching ma terial meet your } \\
\text { expectations? }\end{array}$ & 5.38 & 5.22 \\
\hline $\begin{array}{l}\text { Did you find the exerc ises and assignments } \\
\text { useful? }\end{array}$ & 5.00 & 5.00 \\
\hline $\begin{array}{l}\text { Did you find the online disc ussions with } \\
\text { teacher/ instructor useful? }\end{array}$ & 4.63 & 4.88 \\
\hline $\begin{array}{l}\text { Did you find the commented marking of } \\
\text { assignments useful? }\end{array}$ & 5.25 & 4.78 \\
\hline Average time spend per week on the course & 12 timer 39 min. & 15 timer 40 min. \\
\hline
\end{tabular}

Tabel $1 \quad$ Evaluering af ST111 - vcerdier mellem 1 (lavest) og 6 (højest) 
Et populært kursus er naturligvis ikke ensbetydende med et godt kursus, men da de studerende også har vist et højt fagligt niveau i afleveringsopgaverne og eksamensprojekterne, har jeg tillid til kursets kvalitet.

På trods af kursets succes, valgte jeg at revidere det en smule inden det andet gennemløb i 2005. Formålet hermed var at undgå overlappet med det foregående kursus, at forbedre undervisningsteksten de steder, hvor der havde været usikkerhed eller problemer, og at indsætte flere krydsreferencer og gentagelser i teksten for at styrke sammenhængen i kurset. Enkelte studerende i 2003 havde efterspurgt en ugentlig telefontid, hvilket jeg tilbød holdet i 2005 (de satte pris på tilbuddet, men benyttede det sjældent). Ud over de ugeopdelte faglige diskussionsfora tilføjede jeg i 2005 et socialt forum, hvori de studerende præsenterede sig selv, dannede grupper, og i øvrigt skrev privat med hinanden. Foruden at skabe et bedre socialt netværk blandt kursisterne, var tanken, at aktiviteten på kurset kunne kick-startes i dette forum, hvis de faglige diskussioner skulle sygne hen. Det blev dog aldrig aktuelt.

Igen fungerede kurset fint, både med hensyn til niveauet til eksamen og de studerendes evaluering af kurset.

Prisen for successen med dette kursus er, at det har taget lang tid at forberede, især på grund af det specialudviklede kursusmateriale. Den investerede tid er ikke blevet vundet tilbage på et senere tidspunkt: der kræves lige så meget engagement fra underviseren og stilles lige så mange spørgsmål, (næsten) uanset hvor godt og grundigt kurset er tilrettelagt. Men jeg har oplevet at karakteren og kvaliteten af det, der efterspørges, ændrer sig. Der er færre misforståelser og færre praktiske/tekniske spørgsmål, mens der er flere dybdegående diskussioner og interesse for at finde generaliseringer og overordnede sammenhænge.

\section{Referencer}

Duus, Henrik J., \& Ehlers, Steen, 2004. Succes med e-læring - CME-modellen.” Tidsskrift for universiteternes efter-og videreuddannelse, $\mathrm{nr} .4$.

Georgsen, Marianne, 2003. Læring, kommunikation og samarbejde i virtuelle rum. Tidsskrift for universiteternes efter- og videreuddannelse, nr. 1. 25-33.

Ponti, Marisa \& Ryberg, Thomas, 2004. Rethinking Virtual Space as a Place for Sociability: Theory and Design Implications. Proceedings of Networked Learning Conference NLC2004. http://www.shef.ac.uk/nlc2004/Proceedings/Contents.htm

\section{Web referencer}

Larsen, Pia V. ST111: Regression and analysis of variance. Syddansk Universitet. http://statmaster.sdu.dk/courses/st111/index.html

MASkel: The Master of Applied Statistics course skeleton for educational papers. Syddansk Universitet. http://statmaster.sdu.dk/maskel/ 